\title{
Accumulation and flow rates of ice on Chhota Shigri glacier, central Himalaya, using radio- active and stable isotopes
}

\author{
V. N. NiJampurkaR and D. K. RaO \\ Physical Research Laboratory, Navrangpura, Ahmedabad 380 009, India
}

\begin{abstract}
Systematic isotopic studies based on natural and artificial radioisotopes $\left({ }^{32} \mathrm{Si},{ }^{137} \mathrm{Cs}\right)$, stable isotopes $\left(\delta^{18} \mathrm{O}\right)$ and total $\beta$ activity measurements have been carried out on Chhota Shigri glacier, Himachal Pradesh, central Himalaya, to study the dynamics of the ice, meltwater composition and to identify the deposition of the Chernobyl fall-out in the Himalayan region.

Using ${ }^{32} \mathrm{Si}$ concentrations, the snout ice has been dated at $\sim 250$ years, based on which the past average surface ice-flow rate has been estimated as $\sim 28 \mathrm{~m} \mathrm{year}^{-1}$. Based on $\delta^{18} \mathrm{O}$ variations, in a shallow ice core, the accumulation rate of the ice has been estimated at $\sim 520 \mathrm{~kg} \mathrm{~m}^{-2} \mathrm{year}^{-1}$. ${ }^{32} \mathrm{Si}$ measurements of snout ice and englacial meltwaters indicate that at least $55 \%$ of the snow meltwater mixed with $45 \%$ of the old ice-melt water that emerged from englacial streams in the month of August 1987. Deposition of the artificial radionuclide $\left({ }^{13} \mathrm{Cs}\right)$ and the very high total $\beta$ activity observed in snow samples on Chhota Shigri glacier give the first evidence of Chernobyl fall-out deposition in the Indian Himalaya.
\end{abstract}

\section{INTRODUCTION}

Radioactive and stable isotopes, and chemical tracers, are excellent time markers and climatic indicators which play an important role in the understanding of the past climatic, atmospheric, nuclear and chemical records from both polar and non-polar regions (Delmas and others, 1982; Nijampurkar and others, 1982; Von Gunten and others, 1983; Jouzel and others, 1987). Glaciers and ice caps located at high altitudes of remote areas in tropical latitudes may contain records extending back for periods of a few hundred to several thousands of years (Thompson and others, 1990).

Earlier, long-lived radioisotopes, such as ${ }^{32} \mathrm{Si}$ with a half-life of $\sim 140$ years (Somayajulu and others, 1987; Hofmann and others, in press) and ${ }^{210} \mathrm{~Pb}$ (half-life = 22.3 year) have been used to estimate the ages of young and old ice of several Himalayan glaciers, using the standard radioactivity decay equation and a simple twocomponent flow model. These data, in turn, have been used for estimating surface and basal flow rates of the glacier ice (Nijampurkar and others, 1982; Nijampurkar, 1985). The artificial radionuclide ${ }^{137} \mathrm{Cs}$ and total $\beta$ activities, produced during atmospheric nuclear testing (1950-80) and during nuclear-reactor accidents such as Chernobyl in April 1986, can be used as time-markers to estimate accumulation rates of ice in glaciers (Shukla and others, 1983; Von Gunten and others, 1983; Pourchet and others, 1988).

Using the isotopic composition of oxygen and hydrogen $\left(\delta^{18} \mathrm{O}\right.$ and $\left.\delta \mathrm{D}\right)$ as climatic indicators, much work has been done in polar and semi-polar regions, particularly in Greenland, Antarctica and the Alps (Dansgaard and others, 1969; Ambach and others, 1972; Nijampurkar and others, 1986; Jouzel and others, 1987). The few stable isotopic studies that have been reported for the temperate (Himalaya) and sub-tropical (Dunde Ice Cap) regions indicate that these measurements can also be usefully applied to the study of climatic variations in these regions (Grabczak and others, 1983; Nijampurkar and Bhandari, 1984; Thompson and others, 1988, 1990; Wake, 1989).

Here, we report the results of isotopic studies on Chhota Shigri glacier and discuss them in relation to the pertinent glaciological parameters.

\section{LOGATION AND BASIC FEATURES}

Chhota Shigri glacier, located at $32^{\circ} 19^{\prime} \mathrm{N}, 77^{\circ} 31^{\prime} \mathrm{E}$ at an altitude of $4000-5660 \mathrm{~m}$ (Figs 1 and 2), is a valley-type glacier that lies on the northern ridge of the Pirpanjal range in the Lahul Spiti valley of Himachal Pradesh, Indian Himalaya. From its snout to the accumulation zone near Sara Umga Pass $(4900 \mathrm{~m})$, it extends for a distance of $9 \mathrm{~km}$ and its width varies from 3 to $1.5 \mathrm{~km}$ (Fig. 2). The glacier, located in a mountain range $(4000-$ $6000 \mathrm{~m}$ ) composed mainly of crystalline granitic rocks, is about $10 \mathrm{~km}^{2}$ in area with an equilibrium line that reaches $4700 \mathrm{~m}$ a.s.l. The thickness of the glacier ice varies from 5 to $80 \mathrm{~m}$ between the snout and the accumulation zone; its average thickness is about $55 \mathrm{~m}$. 


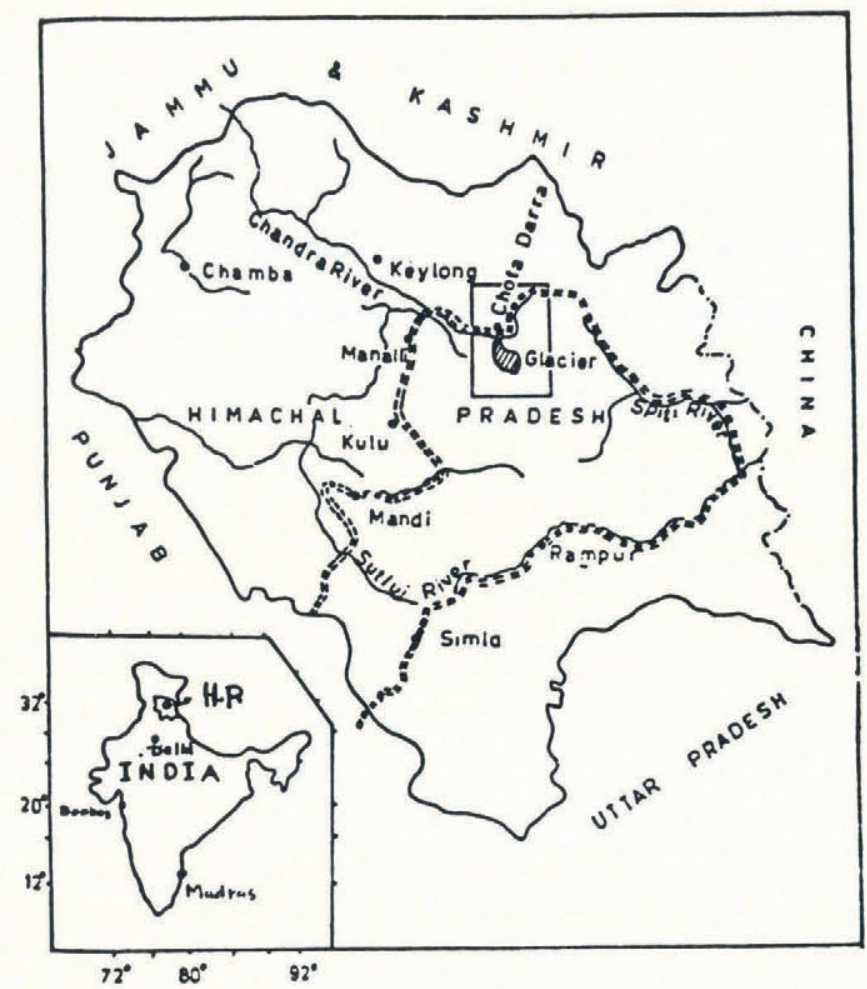

Fig. 1. Map showing the location of Chhota Shigri glacier, Himachal Pradesh, central Himalaya, India.

The tongue of the glacier for about $1 \mathrm{~km}$ above the snout is almost completely covered by surface moraines, while lateral moraines exist all the way along the glacier up to the accumulation zone (Surenderkumar and others, 1987). Ablation in the middle and lower parts of the tongue is very intense. Meltwater from the glacier surface penetrates the ice body and forms subglacial channels, and a few surface meltwater channels are also observed along the sides of the glacier during the summer months. A depression near the snout gets filled with water during the ablation season to form a small supraglacial lake. Near the equilibrium line, old crevasses (generally $20-40 \mathrm{~m}$ in length) get filled and often the surface meltwater penetrates into the ice body to form subglacial channels. Near the equilibrium line in the accumulation zone, where the ice is subjected to considerable pressure, it cracks to form crevasses $40-100 \mathrm{~m}$ long along the length of the glacier. This crevassing makes the working conditions more difficult.

\section{METEOROLOGY, HYDROLOGY AND GLACIO- CHEMISTRY OF THE GLACIER}

The main valley (3000-7000 $\mathrm{m}$ deep), in which the glacier is situated, is dry. The annual precipitation on the glacier is $150-200 \mathrm{~cm}$ of snow $\left(\sim 600 \mathrm{~kg} \mathrm{~m}^{-2}\right.$ year $\left.^{-1}\right)$. During the year the temperature near the terminus varies from $15^{\circ}$ to $-5^{\circ} \mathrm{C}$ and near the snow line from $4^{\circ}$ to $-15^{\circ} \mathrm{C}$. The annual $0^{\circ} \mathrm{C}$ isotherm is at an altitude of $4000 \mathrm{~m}$. The average environmental lapse rate on Chhota Shigri glacier remained pseudo-adiabatic on most days during the summer and varied from $0.38^{\circ}$ to $0.67^{\circ} \mathrm{C} / 100 \mathrm{~m}$ (Bhutiyani and Sharma, 1989).

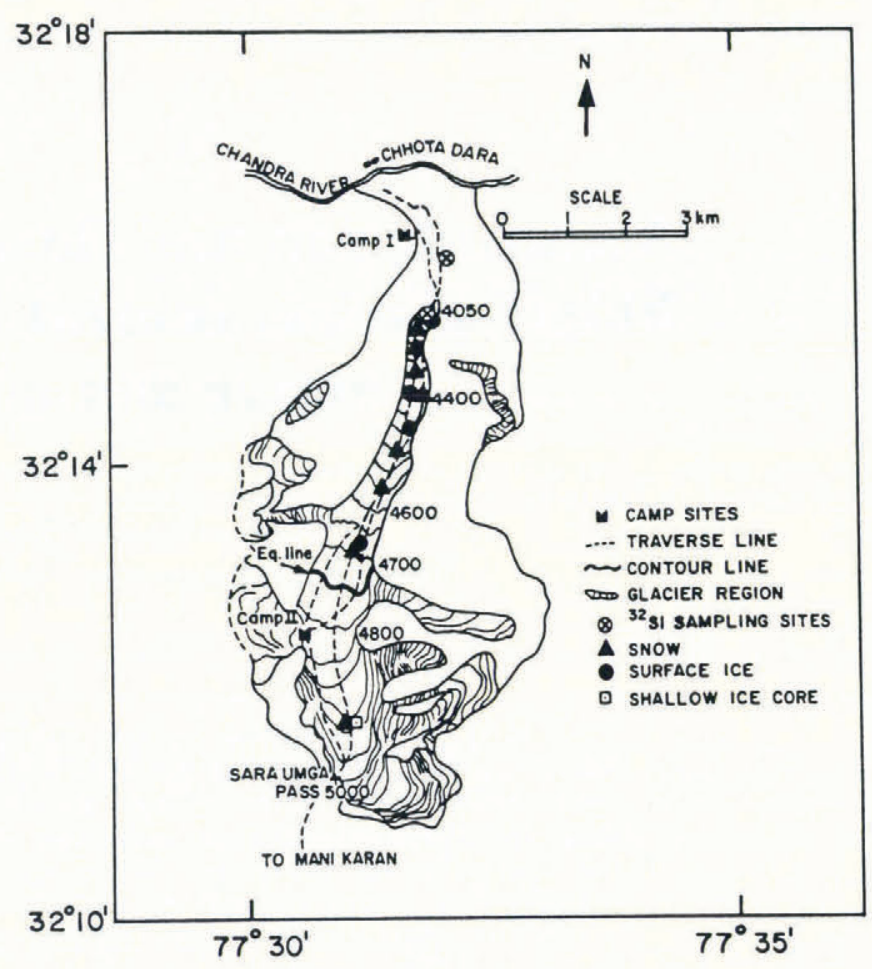

Fig. 2. Sampling sites of snow, surface ice and a shallow ice core collected from Chhota Shigri glacier.

The various positions of the snout line monitored during 1984-86 are an indication of the annual climatic variation on the glacier and have been accompanied by three main episodes of advance and retreat. Fluctuations of the equilibrium line, observed during the same period, support the above observations. The snout line of the glacier continued to recede at a rate of $18.7 \mathrm{myear}^{-1}$ during 1986-88. This retreat was accompanied by a negative mass balance of $155 \times 10^{6} \mathrm{~m}^{3}$ year $^{-1}$ observed during 1987-88.

The chemical composition of snow, surface ice, meltwaters and shallow ice cores has been studied to identify the different sources of origin of the major ions, such as $\mathrm{Na}, \mathrm{K}, \mathrm{Mg}$ and $\mathrm{Cl}$, and the observed seasonal variations have been used to estimate the deposition rates of snow on Chhota Shigri glacier (Nijampurkar and others, 1990).

\section{SAMPLE GOLLEGTION AND ANALYTICAL TECHNIQUES}

\subsection{Sample collection}

During August 1987, we collected about 70 samples of snow, surface ice and shallow ice cores from both the accumulation and ablation zones of Chhota Shigri glacier (Fig. 2) for isotopic studies. These samples ranged from a few millilitres to a thousand litres depending upon the type of study envisaged. For dating snout ice, using cosmic-ray produced ${ }^{32} \mathrm{Si}$, we had to collect samples weighing $1000 \mathrm{~kg}$ due to the low specific activity of ${ }^{32} \mathrm{Si}$ in natural waters.

In addition, we collected large volumes of meltwater from the snout (900l) and from an englacial stream (950l) 
located $100 \mathrm{~m}$ below the snout. Large plastic drums were used for this purpose. These natural waters were spiked with $\mathrm{Na}_{2} \mathrm{SiO}_{3}$ to raise the $\mathrm{Si}$ content of the waters to $\sim 10$ ppm. ${ }^{32} \mathrm{Si}$ activities were scavenged from waters by using freshly precipitated $\mathrm{Fe}(\mathrm{OH})_{3}$ obtained by mixing a $\mathrm{FeCl}_{3}$ solution and $\mathrm{NH}_{4} \mathrm{OH}$ at a $\mathrm{pH}$ of 8 and stirring vigorously for a few hours (Nijampurkar, 1974; Nijampurkar and others, 1982). In this way, more than $90 \%$ of the $\mathrm{SiO}_{2}$ was physically adsorbed on to the $\mathrm{Fe}(\mathrm{OH})_{3}$ matrix which was then separated by decantation. After drying, the $\mathrm{Fe}(\mathrm{OH})_{3}$ was carefully transported to the laboratory. 2 litre samples of snow and surface-ice meltwater were collected at altitudes ranging from 4000 to $4900 \mathrm{~m}$. Additional samples were also collected from a pit and shallow ice core ( $\sim 4 \mathrm{~m}$ depth) at an altitude of $4900 \mathrm{~m}$ in the accumulation zone for measurements of total $\beta$ and artificial $\gamma\left({ }^{137} \mathrm{Cs}\right)$ activities. For the stableisotopic studies, the volumes of the samples collected were generally less than $10 \mathrm{ml}$.

\subsection{Analytical techniques}

Radiochemical analysis of these samples was carried out in the laboratory using a variety of instruments including low-background Geiger Muller counters for ${ }^{32} \mathrm{P}$ and total $\beta$-activity measurements, a high-efficiency well-type highpurity germanium (HPGe) detector system for $\gamma$-activity measurements and a mass spectrometer for stable-isotopic studies.

\section{2(a). Radiochemical purification and assay of ${ }^{32} P$}

Silica containing radioactive ${ }^{32} \mathrm{Si}$ was separated from the $\mathrm{Fe}(\mathrm{OH})_{3}$ matrix using standard procedures (Nijampurkar and others, 1982) and was allowed to equilibrate with ${ }^{32} \mathrm{P}$, its daughter radioisotope, which is convenient to use due to its short half-life of $14.3 \mathrm{~d} .{ }^{32} \mathrm{Si}$ was counted via ${ }^{32} \mathrm{P}$ (after radiochemical separation and purification as $\mathrm{Mg}_{2} \mathrm{P}_{2} \mathrm{O}_{7}$ ) on a low-background (1.5 cph) Geiger Muller counter with a $\mathrm{NaI}(\mathrm{T} 1)$ detector in anti-coincidence with a counting efficiency of $25 \%$. The ${ }^{32} \mathrm{P}$ activity was counted for several half lives (Fig. 3) and the initial ${ }^{32} \mathrm{Si}$ activities were calculated.

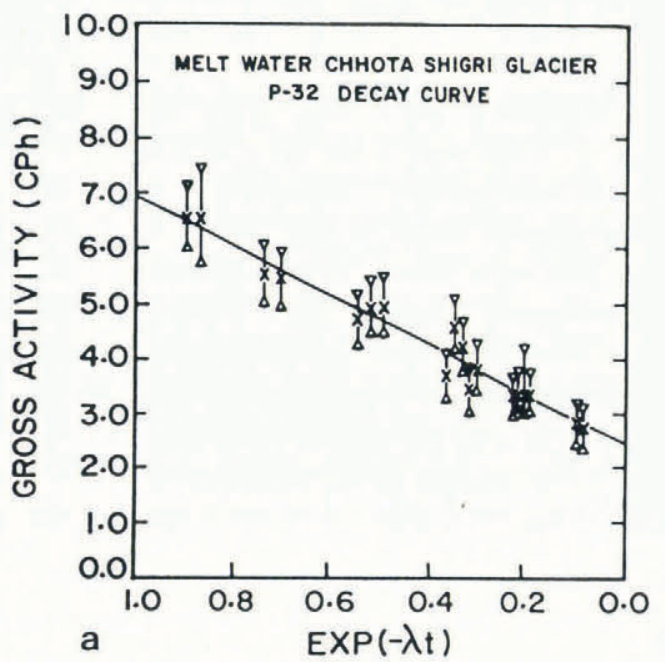

\section{2(b). Total $\beta$-activity measurements}

Melted samples of snow, surface ice and shallow ice cores ranging in volume from 1 to 21 were acidified with 1: $1 \mathrm{HNO}_{3}$ and filtered to remove suspended dust. The filtrate was evaporated to dryness and its residue as well as the suspended dust were counted separately within a few weeks after collection to study the dissolved and adsorbed component on the dust of total $\beta$ activity, on a lowbackground Geiger Muller counter, as described in section 4.2 (a). Generally, $\sim 70 \%$ activity was observed in the solutions. However, the combined $\beta$ activity of the dissolved and suspended components has been taken into account for calculations and discussions.

\section{2(c). $\gamma$-activity measurements}

A high-resolution and high-efficiency well-type germanium detector ( $130 \mathrm{~cm}^{3}$ volume) was used to obtain very low concentrations of ${ }^{137} \mathrm{Cs}$ in snow and ice samples collected from Chhota Shigri glacier. The efficiency and resolution of the detector at $661.6 \mathrm{keV}$ energy are $6.4 \%$ and $1.7 \mathrm{keV}$, respectively. Following the total $\beta$-activity measurements, the residue and the suspended dust were mixed together and counted for ${ }^{137} \mathrm{Cs}$ activities in specially made plastic vials.

\section{$4.2(\mathrm{~d}) \cdot \delta^{18} \mathrm{O}$ measurements}

Meltwater samples measuring about $10 \mathrm{ml}$ were collected and transported in airtight plastic bottles to the laboratory where they were kept frozen to prevent evaporation until measurement. Oxygen-isotope analyses were carried out with a mass spectrometer (VG Micromass 602 D) at the Physical Research Laboratory using standard procedures (Bhattacharya and others, 1985).

\section{RESULTS AND DISCUSSION}

\subsection{Dating of glacier snout ice and meltwater by ${ }^{32} \mathrm{Si}$}

Using a half-life value of 140 years for ${ }^{32} \mathrm{Si}$ (Somayajulu

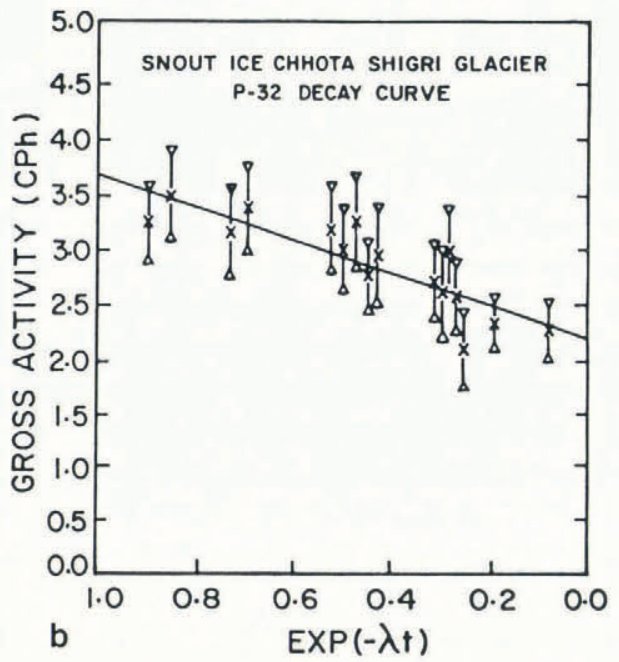

Fig. 3. Decay curve of ${ }^{32} P$ for (a) meltwater and (b) the snout. The ${ }^{32}$ Si concentrations are calculated using the net ${ }^{32} P$ activity. 
Table $1 .{ }^{32}$ Si concentrations in snout and meltwater samples from Chhota Shigri glacier

\begin{tabular}{|c|c|c|c|c|c|c|}
\hline $\begin{array}{l}\text { Sample } \\
\text { code }\end{array}$ & $\begin{array}{l}\text { Nature } \\
\text { altitude }\end{array}$ & $\begin{array}{l}\text { Volume } \\
\text { processed }\end{array}$ & ${ }^{32} P$ activity & $\begin{array}{c}{ }^{*} 32 \text { Si concen- } \\
\text { tration }\end{array}$ & $\begin{array}{c}\text { Radiometric } \\
\text { age }\end{array}$ & $\begin{array}{l}\text { Surface ice- } \\
\text { flow rate }\end{array}$ \\
\hline & $\mathrm{m}$ & 1 & cph & $\mathrm{dpm} / 10^{3} 1$ & year & m year ${ }^{-1}$ \\
\hline CS-1 & $\begin{array}{c}\text { Snout ice } \\
(4100)\end{array}$ & 900 & $1.50 \pm 0.25$ & $0.21 \pm 0.04$ & 250 & 28 \\
\hline CS-2 & $\begin{array}{c}\text { Meltwater } \\
\text { (discharge } \\
\text { point) } \\
(4000)\end{array}$ & 950 & $4.44 \pm 0.26$ & $0.47 \pm 0.03$ & 80 & - \\
\hline
\end{tabular}

*These samples were collected in August 1987.

and others, 1987; Hofmann and others, in press) and assuming the average value of ${ }^{32} \mathrm{Si}$ concentration in the snow precipitation in the Himalayan region to be $0.7 \mathrm{dpm} /$ $10^{3} 1$ (Nijampurkar and others, 1982), a radiometric age of 250 years for the snout ice is obtained, based on its measured ${ }^{32} \mathrm{Si}$ concentration of $0.2 \pm 0.02 \mathrm{dpm} / 10^{3} 1$ (Table 1). The basic assumption made in using the ${ }^{32} \mathrm{Si}$ dating method is that the production rate as well as the fall-out of ${ }^{32} \mathrm{Si}$ over the Himalyan region has remained constant over the past few centuries based on a fairly constant cosmic-ray flux during that period (Lal and Peters, 1967).

Using the radiometric age of 250 years for the snout ice and the length of the glacier, the average surface iceflow rate over the past few centuries is calculated to be 28 m year $^{-1}$. Comparison with the modern surface ice-flow rate of 23 m year $^{-1}$ based on conventional survey methods (personal communication from V.B. Bahuguna) indicates that the glacier is not in a steady state.

Using a measured ${ }^{32} \mathrm{Si}$ concentration in the meltwater (sample CS-2, Table 1) of $0.47 \pm 0.05 \mathrm{dpm} / 10^{3} 1$, the radiometric age of the average meltwater has been estimated to be 80 years. This suggests a mix of at least $55 \%$ snowmelt with $\sim 45 \%$ of old ice melt that emerges from the supraglacial lake of Chhota Shigri glacier.

\subsection{Deposition of Chernobyl fall-out on Chhota Shigri glacier}

The artificial radioactivity discharged into the atmosphere following the Chernobyl accident of 26 April 1986 was deposited via precipitation and dry fall-out depending upon the extent of the atmospheric circulation pattern. Since 1986, radioactivity from Chernobyl has been monitored worldwide in aerosols, rainwater, fresh snow, ocean water, lake sediments and milk products (Csongar and others, 1986; Nishizawa and others, 1986; Ambach and others, 1987; Mélières and others, 1988; Mitchell and others, 1988; Pourchet and others, 1988).

\section{2(a). Total $\beta$-activity measurements}

The total $\beta$ activities in snow, surface ice and shallow ice- core samples were measured within a few weeks of their collection and the results are given in Table 2. It appears that the total $\beta$ activity (with an average value of $4100 \mathrm{dph}^{-1}$ ) measured in snow samples collected in the altitude range $4150-4650 \mathrm{~m}$ (see Fig. 4) is larger by a factor of about 8 than that observed in the surface-ice samples $\left(\sim 500 \mathrm{dph}^{-1}\right)$ collected from the same locations on the glacier. Although the peak total $\beta$ activity $\left(8400 \mathrm{dpl}^{-1}\right)$ observed in the snow sample collected from an altitude of $4550 \mathrm{~m}$ is much higher (by a factor of about 17) than that observed in surface-ice samples, the activities observed during the present work in the Himalaya are lower by a factor of about 20 than those observed in the European Alps (Ambach and others, 1989).

\section{2(b). Artificial $\gamma$-activity measurements}

A host of fission products (artificial radionuclides) like ${ }^{144} \mathrm{Ce},{ }^{137} \mathrm{Cs},{ }^{134} \mathrm{Cs},{ }^{125} \mathrm{Sb},{ }^{103} \mathrm{Ru},{ }^{95} \mathrm{Zr}$, etc. were produced during the Chernobyl accident (Sadasivan and Mishra, 1986). Only ${ }^{137} \mathrm{Cs}$ with a longer half-life (30 year) could be identified in the $\gamma$-ray spectrum of snow samples collected at different altitudes (Table 2).

${ }^{137} \mathrm{Cs}$ activities in snow and surface-ice samples are given in Table 2. Values range from 10 to $255 \mathrm{dphl}^{-1}$ in snow and from 10 to $27 \mathrm{dph}^{-1}$ in surface ice. It is evident from Figure $4 \mathrm{~b}$ that the higher ${ }^{137} \mathrm{Cs}$ activities occur in snow samples deposited in the altitude range of 4150 $4650 \mathrm{~m}$. Average value of $120 \mathrm{dph}^{-1}$ and a peak activity of $255 \mathrm{dph}^{-1}$ at $4550 \mathrm{~m}$ are higher by factors of about 7 and 15 , respectively, than those measured in the surface-ice samples (17 and $27 \mathrm{dph}^{-1}$, respectively). Surprisingly, we did not observe high total $\beta$ and ${ }^{137} \mathrm{Cs}$ activities in samples collected at different depths from a $1 \mathrm{~m}$ snow pit $(4700 \mathrm{~m})$ and a $4 \mathrm{~m}$ shallow ice core $(4900 \mathrm{~m})$ from the accumulation zone. These results support earlier findings on the distribution of total $\beta$ activities on Chhota Shigri glacier, showing that the radioactive cloud bearing Chernobyl fallout did not penetrate or diffuse beyond $4700 \mathrm{~m}$ altitude over the glacier and that its deposition in the Himalaya is much lower, by a factor of at least 15 , than that deposited in the Swiss Alps (Haeberli and others, 1988).

The depositional characteristics of Chernobyl fall-out 
Table 2. Deposition of total $\beta$ and ${ }^{137}$ Cs activities at different altitudes on Chhota Shigri glacier

\begin{tabular}{|c|c|c|c|c|}
\hline \multirow{2}{*}{$\begin{array}{l}\text { Sample } \\
\text { altitude }\end{array}$} & \multicolumn{2}{|c|}{$\begin{array}{c}\text { Total } \beta \text { activity } \\
\qquad \mathrm{dph} \mathrm{l}^{-1}\end{array}$} & \multicolumn{2}{|c|}{$\begin{array}{c}{ }^{137} \text { Cs activity } \\
\mathrm{dph} \mathrm{l}^{-1}\end{array}$} \\
\hline & Snow & Ice & Snow & Ice \\
\hline 4100 & $766 \pm 12$ & $390 \pm 8$ & $10 \pm 10$ & $16 \pm 5$ \\
\hline 4150 & $2305 \pm 70$ & - & $38 \pm 7$ & - \\
\hline 4250 & - & - & $141 \pm 6$ & - \\
\hline 4350 & $4306 \pm 82$ & $248 \pm 8$ & $93 \pm 10$ & $15 \pm 12$ \\
\hline 4450 & $3911 \pm 85$ & $878 \pm 19$ & $119 \pm 32$ & $10 \pm 15$ \\
\hline 4550 & $8413 \pm 235$ & $=$ & $255 \pm 30$ & $\overline{-}$ \\
\hline 4650 & $1613 \pm 25$ & $616 \pm 8$ & $70 \pm 15$ & $27 \pm 6$ \\
\hline 4900 & $656 \pm 15$ & - & $15 \pm 30$ & - \\
\hline
\end{tabular}

Notes

(i) Total $\beta$ activities in snow and ice samples were measured separately in filtrate and suspended material and the total activity is given in the table.

(ii) The samples were collected in August 1987 and analysed for total $\beta$ activities in March 1988. The ${ }^{137} \mathrm{Cs}$ activities were, however, counted in March-June 1990 after the HPGe well-type system was purchased.

on Chhota Shigri glacier can be explained in the following way. Snow deposited during the winter months in the accumulation zone survives the summer, lasting from April to October, whereas most of the snow deposited close to the equilibrium line ( $4700 \mathrm{~m}$ a.s.l.) melts away in the summer. The snow that persists in the ablation zone until mid-summer (July-August) represents deposition that occurred in the early winter months of November and December, and which enabled us to monitor the
Chernobyl fall-out in this region. However, near the snout region $(4050 \mathrm{~m})$, snow that falls early in the winter probably melts away due to higher temperatures over the thick debris cover. The snow that survives into midsummer was deposited later in the winter, i.e. from December to March, and as a result we could not observe any activity in the sample collected at $4050 \mathrm{~m}$ near the snout.

It has been observed that most of the Chernobyl fall-

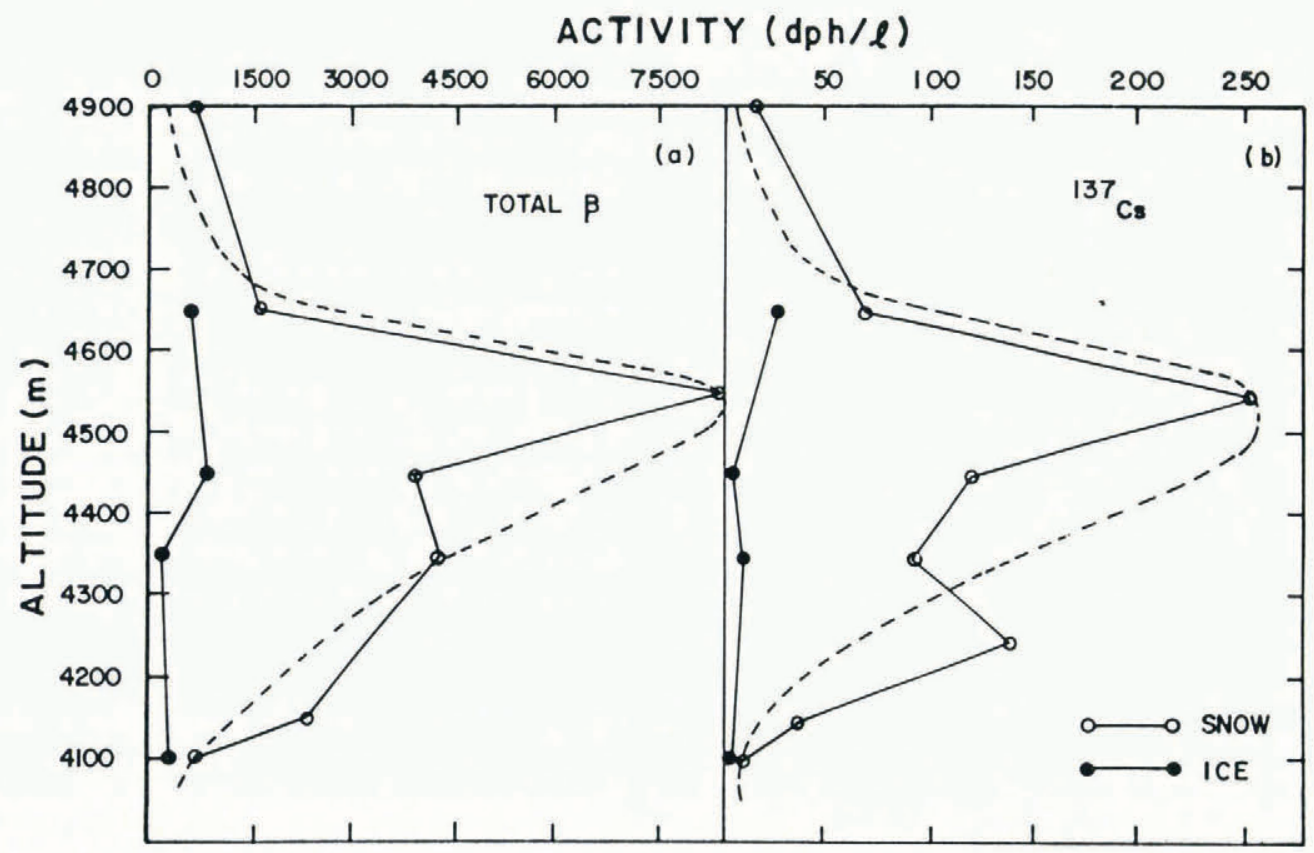

Fig. 4. Variations of total $\beta$ and ${ }^{137} \mathrm{Cs}$ activities $\left(d p h l^{-1}\right)$ in snow and surface-ice samples from different altitudes on Chhota Shigri glacier. These activities are for fall-out deposited in the altitude range of 4150-4650 $\mathrm{m}$. The dotted line shows the model curve for the deposition of Chernobyl fall-out on the glacier. 
out was deposited in the regions immediately adjacent to the accident site in May 1986. The fall-out has been monitored at different locations up to an altitude of $4250 \mathrm{~m}$ in the European Alps (Ambach and others, 1987, 1989; Haeberli and others, 1988; Pourchet and others, 1988). It is known from earlier studies (Csongar and others, 1986; Fry and others, 1986) that the Chernobyl fall-out was scavenged mostly by the wet precipitation process and that scavenging by snowfall was found to be similar to that observed with wet precipitation. Additionally, it is observed that most of the radioactive fall-out $(>90 \%)$ occurred on a few rainy days or in snow that was deposited within a period of 2 weeks after the accident. Assuming that the same process dominates in the Himalaya, one would expect the Chernobyl fall-out to have been deposited with the snow that fell during November and December 1986.

A fraction of the radioactive plume must also have spread over the $30-40^{\circ} \mathrm{N}$ latitude belt over the Mediterranean Sea and subsequently was transported over the Himalayan region in the course of time along with the western winds and by a process of diffusion. It is difficult to know how long it should have taken for the radioactiveplume front carried by the winds to reach the Himalayan region. But, certainly, the radioactive clouds were transported to the Lahual Spiti valley (where Chhota Shigri glacier is situated), where fall-out on the glacier occurred either by a process of dry deposition of aerosols or in snow deposited during the early winter months (November-December).

The results of the present work confirm for the first time deposition of Chernobyl fall-out on Chhota Shigri

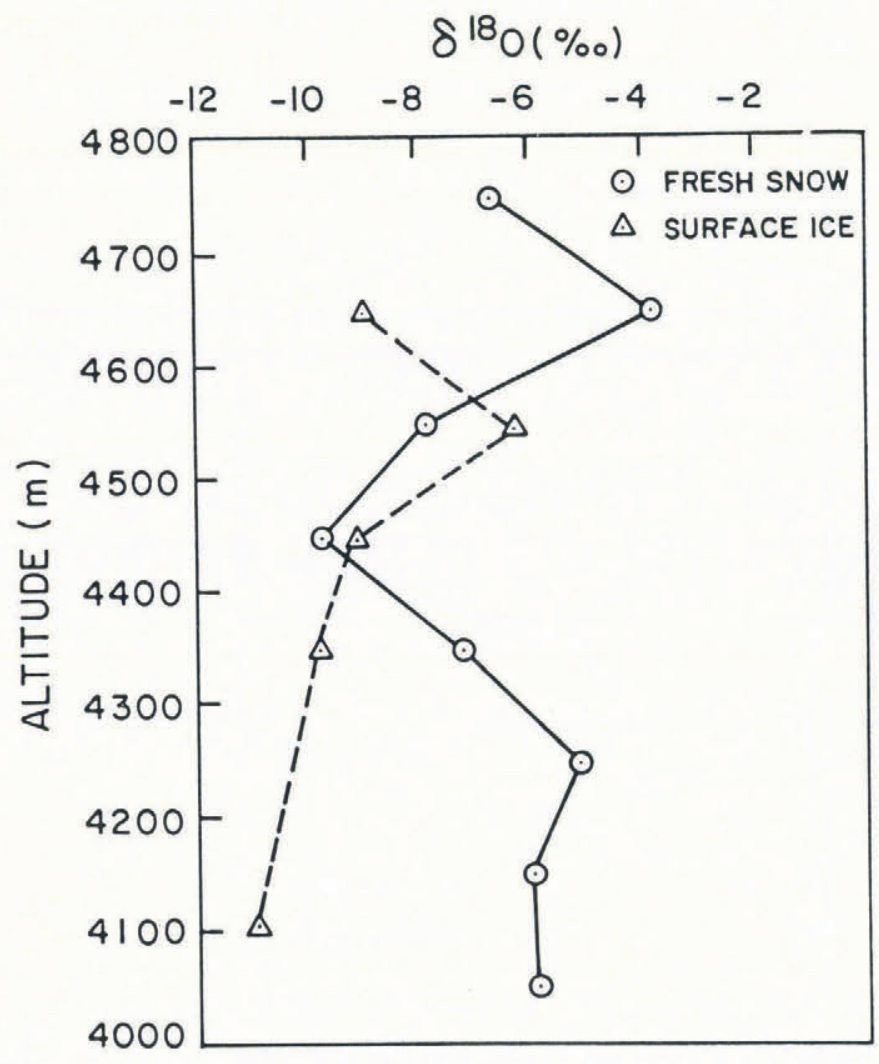

Fig. 5. Variation of $\delta^{18} \mathrm{O}$ in snow and surface-ice samples at different altitudes along the glacier. No systematic variation of $\delta^{18} \mathrm{O}$ is observed with altitude for the snow samples.

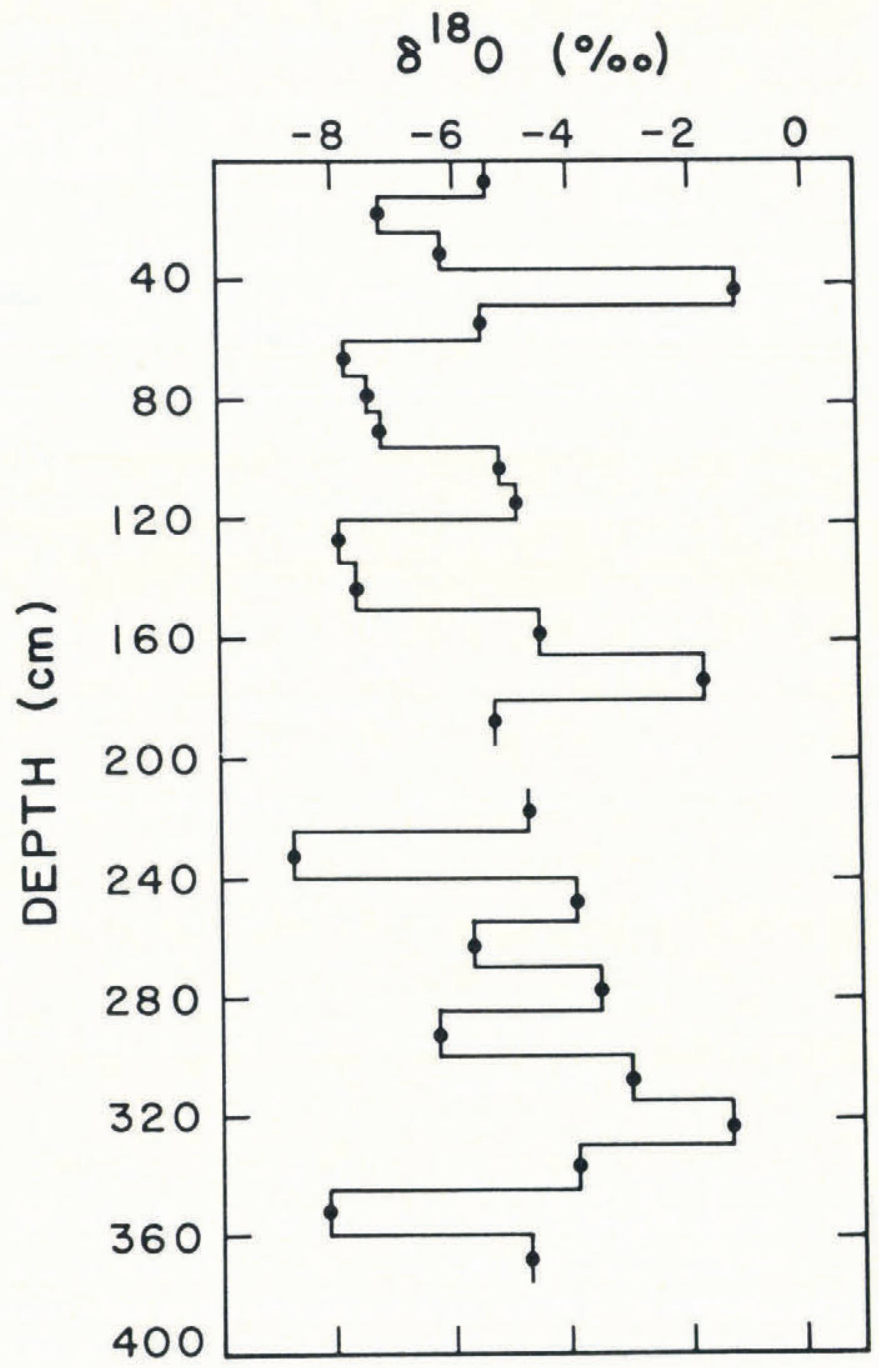

Fig. 6. Depth profile of $\delta^{18} \mathrm{O}$ in a $4 \mathrm{~m}$ shallow ice core from an altitude of $4900 \mathrm{~m}$ in the accumulation zone. The deposition rate of snow has been estimated to be $520 \mathrm{~kg} \mathrm{~m}^{-2}$ year ${ }^{-1}$, using seasonal variations in $\delta^{18} \mathrm{O}$ values.

glacier. The results also show that a very small fraction of the Chernobyl fall-out was deposited in the Himalaya compared to that in the Alps.

\subsection{Isotopic composition $\left(\delta^{18} O\right)$ of snow, ice and core samples}

The isotopic composition of snow deposited at high altitudes in the mountains depends primarily on the surface-air temperature, circulation pattern and the source of the moisture. The $\delta^{18} \mathrm{O}$ values of different samples obtained, in comparison with that of SMOW, are shown in Figures 5 and 6 . The following observations emerge from the data.

\section{$5.3(\mathrm{a}) \cdot \delta^{18} \mathrm{O}$ variation with altitude in snow and ice}

Figure 5 shows the results of the analyses of the snow and surface-ice samples collected at different altitudes, both in the accumulation and ablation zones of Chhota Shigri glacier. The snow samples span an elevation of about $700 \mathrm{~m}$ and show $\delta^{18} \mathrm{O}$ values fluctuating in the range -4 to $-10 \%$ with a mean value of $-7 \pm 3 \%$. According to 
Niewodniczanski and others (1981), no systematic dependence of $\delta^{18} \mathrm{O}$ on altitude is observed in the sampling range $4050-4750 \mathrm{~m}$. Our observations are similar to those of Ambach and others (1986), Wushiki (1977) and Nijampurkar and Bhandari (1984), which also fail to indicate any altitude dependence in isotopic fractionation. As expected, values are much higher than those observed in Changme Khangfu glacier, Sikkim valley $(-19 \pm 2 \%$ ), as the snow samples were collected from higher altitudes $(4900-5400 \mathrm{~m}) \cdot \delta^{18} \mathrm{O}$ values of the surface-ice samples collected from altitudes between 4100 and $4600 \mathrm{~m}$ range from -6 to $-11 \%$ with a mean value of $-8.5 \pm 2.5 \%$. These values are again higher than those observed for surface-ice samples from Changme Khangfu glacier which range from -12 to $-17 \%$ with an average value of $-14.5 \pm 2.5 \%$.

The average $\delta^{18} \mathrm{O}$ value of samples of snout ice is found to be $-11 \pm 0.1 \%$ which is the lowest of all the values so far observed on Chhota Shigri glacier. The radiometric age of the snout ice, based on ${ }^{32} \mathrm{Si}$ measurements, has been estimated at 250 years. The data therefore indicate that climatic conditions two centuries ago were appreciably cooler than the present-day ones.

\section{$5.3(\mathrm{~b}) . \delta^{18} \mathrm{O}$ variation in a shallow core}

As discussed earlier, the snowfall on Chhota Shigri glacier generally takes place from November to March. The average surface-air temperatures for the period February and March are usually higher by about $14^{\circ} \mathrm{C}$ (personal communication from N.V. Apte, India Meteorology Department, New Delhi) than those during NovemberJanuary. Accordingly, $\delta^{18} \mathrm{O}$ values of the snow deposited during February-March should, as observed in a $4 \mathrm{~m}$ core, be less negative by about $7 \%$ than those deposited during November-January.

The results of the $\delta^{18} \mathrm{O}$ measurements on samples from a shallow pit and core from $4.0 \mathrm{~m}$ depth at $4900 \mathrm{~m}$ in the accumulation zone of the glacier are shown in Figure 6. The $\delta^{18} \mathrm{O}$ values fluctuate between -1 and $-9 \%$ with a mean value of $-5.3 \%$. The peak values observed around $0.4,1.7$ and $3.0 \mathrm{~m}$ suggest annually repeating cycles of about $1.30 \mathrm{~m}$ of snow, equivalent to a deposition rate of snow of about $520 \mathrm{~kg} \mathrm{~m}^{-2} \mathrm{year}^{-1}$. This value agrees reasonably well with the $600 \mathrm{~kg} \mathrm{~m}^{-2}$ year $^{-1}$ estimated from the seasonal variations of major ions observed in the same ice core (Nijampurkar and others, 1990).

\section{CONCLUSIONS}

1. Using cosmogenic ${ }^{32} \mathrm{Si}$ activities in precipitation and ice from the snout of Chhota Shigri glacier, the radiometric age of the snout ice has been estimated at $\sim 250$ years. The average flow rate of the glacier over the past few centuries has been estimated at $\sim 28 \mathrm{~m} \mathrm{year}^{-1}$.

2. ${ }^{32} \mathrm{Si}$ studies on englacial meltwaters indicate that they consist of at least $55 \%$ snow meltwater and $45 \%$ old-ice meltwater.

3. The identification of the artificial radionuclide ${ }^{137} \mathrm{Cs}$ in snow samples collected in August 1987 confirms the presence of Chernobyl fall-out on Chhota Shigri glacier, Indian Himalaya.
4. The average $\delta^{18} \mathrm{O}$ value of snout ice is depleted by $5.7 \%$ compared to the average value obtained on a $4 \mathrm{~m}$ shallow ice core. This ice core represents the snow accumulated in the 2 years prior to August 1987 which would indicate that the climatic conditions a few centuries ago were appreciably cooler than that at present.

5. Based on $\delta^{18} \mathrm{O}$ variations in a shallow ice core, the snow accumulation on Chhota Shigri glacier, averaged for the 2 years prior to August 1987, has been calculated as $520 \mathrm{~kg} \mathrm{~m}^{-2}$ year $^{-1}$.

\section{ACKNOWLEDGEMENTS}

This project was financed by the Indian Department of Science and Technology. We are especially grateful to $\mathrm{Dr}$ M.N. Qureshi of the Department of Science and Technology, New Delhi, and Dr Surendrakumar of the Wadia Institute of Himalayan Geology, leader of the expedition, and his colleagues for their kind help in collecting samples. We are also grateful to Professor B.L.K. Somayajulu for his co-operation during the work, Dr R. Ramesh for useful discussions and Mr R. A. Jani for $\delta^{18} \mathrm{O}$ measurements.

\section{REFERENCES}

Ambach, W., W. Dansgaard, H. Eisner and J. Møller. 1968. The altitude effect on the isotopic composition of precipitation and glacier ice in the Alps. Tellus, 20, 595600.

Ambach, W., H. Eisner and K. Pessl. 1972. Isotopic oxygen composition of firn, old snow and precipitation in Alpine regions. Z. Gletscherkd. Glazialgeol., 8(1-2), 125-135.

Ambach, W., W. Rehwald, M. Blumthaler and H. Eisner. 1987. Chernobyl fallout on Alpine glaciers: a new reference horizon for dating. EOS, 68(45), 1577.

Ambach, W., W. Rehwald, M. Blumthaler, H. Eisner and P. Brunner. 1989. Chernobyl fallout on Alpine glaciers. Health Phys., 56(1), 27-31.

Bhattacharya, S. K., S. K. Gupta and R. V. Krishnamurthy. 1985. Oxygen and hydrogen isotopic ratios in ground waters and river waters from India. Proc. Indian Acad. Sci. (Earth Planet. Sci.), 94(3), 283-295.

Bhutiyani, M. R. and M. C. Sharma. 1989. A report on the glaciological studies carried out on Chhota Shigri glacier. Technical Report of the Multi-disciplinary Glacier Expedition to Chhota Shigri glacier. New Delhi, Department of Science and Technology, 203-236. (Report 3.)

Bondietti, E., A.J.N. Brantley and C. Rengarajan. 1988. Size distributions and growth of natural and Chernobyl derived submicron aerosols in Tennessee. 7. Environ. Radioactivity, 6, 99-120.

Csongor, E., A.Z. Kiss, B. M. Nyako and E. Somorjai. 1986. Chernobyl fallout in Debrecen, Hungary. Nature, 324(6094), 216.

Dansgaard, W., S.J. Johnsen, J. Møller and C.C. Langway, Jr. 1969. One thousand centuries of climatic record from Camp Century on the Greenland ice sheet. Science, 166, 377-381.

Delmas, R., M. Brait and M. Legrand. 1982. Chemistry of 
south polar snow. 7. Geophys. Res., 87(C6), 43144318.

Fry, F. A., R.H. Clarke and M. C. O'Riordam. 1986. Early estimates of UK radiation doses from the Chernobyl reactor. Nature, 321(6067), 193-195.

Grabczak, J., J. Niewodniczański and K. Rỏżański. 1983. Isotope stratification in high mountain glaciers: examples from the Peruvian Andes and Himalaya. 7. Glaciol., 29(103), 417-424.

Haeberli, W., H. Gäggeler, U. Baltensperger, D. Jost and U. Schotterer. 1988. The signal from the Chernobyl accident in high-altitude firn areas of the Swiss Alps. Ann. Glaciol., 10, 48-51.

Hofmann, H.J., G. Bonani, M. Suter, W. Wolfli, D. Zimmermann and H. R. von Gunten. In press. A new determination of the half-life of ${ }^{32} \mathrm{Si}$. Nucl. Instrum. Methods.

Jouzel, J. and 6 others. 1987. Vostok ice core: a continuous isotope temperature record over the last climatic cycle (160,000 years). Nature, 329(6138), 403-408.

Lal, D. and B. Peters. 1967. Cosmic ray produced radioactivity on the Earth. In Encyclopedia of physics, Vol. XLVI/2. Berlin, Springer-Verlag, 551-612.

Mélières, M. A., M. Pourchet, J.F. Pinglot, R. Bouchez and M. Piboule. 1988. Chernobyl ${ }^{134} \mathrm{Cs},{ }^{137} \mathrm{Cs}$ and ${ }^{210} \mathrm{~Pb}$ in high mountain lake sediment; measurements and modeling of mixing process. 7. Geophys. Res., 93(D6), 7055-7061.

Mitchell, N., T. Steele and A. K. Steele. 1988. The marine impact of ${ }^{134} \mathrm{Cs}$ and ${ }^{137} \mathrm{Cs}$ from the Chernobyl reactor accident. 7. Environ. Radioactivity, 6, 163-175.

Niewodniczański, J., J. Grabczak, L. Baranski and J. Rzepka. 1981. The altitude effect on the isotopic composition of snow in high montains. 7. Glaciol., 27(95), 99-111.

Nijampurkar, V.N. 1974. Applications of cosmic ray produced isotope silicon-32 to hydrology with special reference to dating of groundwaters. (Ph.D. thesis, University of Bombay, India.)

Nijampurkar, V.N. 1985. Basal flow rate of ChangmeKhangpu glacier, Sikkim Himalaya based on ${ }^{32} \mathrm{Si}$ and ${ }^{210} \mathrm{~Pb}$ chronology. Proc. Indian Acad. Sci. (Earth Planet. Sci.), 94(2), 83-89.

Nijampurkar, V.N. and N. Bhandari. 1984. Oxygen

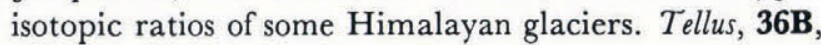
300-302.

Nijampurkar, V.N., N. Bhandari, C.P. Vohra and V. Krishnan. 1982. Radiometric chronology of Neh-nar glacier, Kashmir. f. Glaciol., 28(98), 91-105.
Nijampurkar, V. N., N. Bhandari, R. Ramesh and S. K. Bhattacharya. 1986. Climatic significance of $\mathrm{D} / \mathrm{H}$ ratios of a temperate glacier in Sikkim. Curr. Sci., 55(18), 910 912.

Nijampurkar, V. N., M. M. Sarin and D. K. Rao. In press. Chemical composition of snow and ice on Chhota Shigri glacier, central Himalaya. Tellus.

Nishizawa, K. and 7 others. $1986 .{ }^{131} \mathrm{I}$ in milk and rain after Chernobyl. Nature, 324(6095), 308.

Pourchet, M., J. F. Pinglot, L. Reynaud and G. Holdsworth. 1988. Identification of Chernobyl fall-out as a new reference level in Northern Hemisphere glaciers. $\mathcal{F}$. Glaciol., 34(117), 183-187.

Sadasivan, S. and U. C. Mishra. 1986. Radioactive fallout swipe samples from Chernobyl. Nature, 324(6092), 23.

Shukla, P. N., N. Bhandari, V. N. Nijampurkar, D. K. Rao, V.M.K. Puri and S. Sharma. 1983. Ice accumulation rate in Changme-Khangpu glacier, Sikkim. Proc. Indian Acad. Sci. (Earth Planet. Sci.), 92(3), 255-260.

Somayajulu, B. L. K., R. Rengarajan, D. Lal, R. F. Weiss and H. Craig. 1987. GEOSEC Atlantic ${ }^{32} \mathrm{Si}$ profiles. Earth Planet. Sci. Lett., 85, 329-342.

Surendarkumar, K., H. Rai, K.K. Purohit, B.R.S. Rawat and A.K. Mundepi. 1987. About Chhota Shigri glacier. Technical Report of the Multi-disciplinary Expedition to Chhota Shigri glacier. New Delhi, Department of Science and Technology. (Report 1.)

Thompson, L. G., X. Wu, E. M. Mosley-Thompson and Z. Xie. 1988. Climatic records from the Dunde ice cap, China. Ann. Glaciol., 10, 178-182.

Thompson, L. G. and 9 others. 1990. Glacial stage ice-core records from the subtropical Dunde ice cap, China. Ann. Glaciol., 14, 288-297.

Von Gunten, H. R., E. Rössler and H. Gäggeler. 1983. Dating of ice cores from Vernagtferner (Austria) with fission products and lead-210. Z. Gletscherkd. Glazialgeol., 18(1), 1982, 37-45.

Wake, C. P. 1989. Glaciochemical investigations as a tool for determining the spatial and seasonal variation of snow accumulation in the central Karakoram, northern Pakistan. Ann. Glaciol., 13, 279-284.

Wushiki, H. 1977. Altitude effect on the deuterium content of the local rains and snows in the Himalayas. Seppyo, 39, Special Issue, 57-59.

The accuracy of references in the text and in this list is the responsibility of the authors, to whom queries should be addressed. 